\title{
The Role of CREB, SRF, and MEF2 in Activity-Dependent Neuronal Plasticity in the Visual Cortex
}

\author{
Nisha S. Pulimood, Wandilson dos Santos Rodrigues Junior, Devon A. Atkinson, Sandra M. Mooney, \\ and Alexandre E. Medina \\ University of Maryland School of Medicine, Baltimore, Maryland 21201
}

\begin{abstract}
The transcription factors CREB (cAMP response element binding factor), SRF (serum response factor), and MEF2 (myocyte enhancer factor 2) play critical roles in the mechanisms underlying neuronal plasticity. However, the role of the activation of these transcription factors in the different components of plasticity in vivo is not well known. In this study, we tested the role of CREB, SRF, and MEF2 in ocular dominance plasticity (ODP), a paradigm of activity-dependent neuronal plasticity in the visual cortex. These three proteins bind to the synaptic activity response element (SARE), an enhancer sequence found upstream of many plasticity-related genes (Kawashima et al., 2009; Rodríguez-Tornos et al., 2013), and can act cooperatively to express Arc, a gene required for ODP (McCurry et al., 2010). We used viral-mediated gene transfer to block the transcription function of CREB, SRF, and MEF2 in the visual cortex, and measured visually evoked potentials in awake male and female mice before and after a $7 \mathrm{~d}$ monocular deprivation, which allowed us to examine both the depression component (Dc-ODP) and potentiation component (Pc-ODP) of plasticity independently. We found that CREB, SRF, and MEF2 are all required for ODP, but have differential effects on Dc-ODP and Pc-ODP. CREB is necessary for both Dc-ODP and Pc-ODP, whereas SRF and MEF2 are only needed for Dc-ODP. This finding supports previous reports implicating SRF and MEF2 in long-term depression (required for Dc-ODP), and CREB in long-term potentiation (required for Pc-ODP).
\end{abstract}

Key words: CREB; MEF2; plasticity; SRF; transcription factors; visual cortex

\section{Significance Statement}

Activity-dependent neuronal plasticity is the cellular basis for learning and memory, and it is crucial for the refinement of neuronal circuits during development. Identifying the mechanisms of activity-dependent neuronal plasticity is crucial to finding therapeutic interventions in the myriad of disorders where it is disrupted, such as Fragile X syndrome, Rett syndrome, epilepsy, major depressive disorder, and autism spectrum disorder. Transcription factors are essential nuclear proteins that trigger the expression of gene programs required for long-term functional and structural plasticity changes. Our results elucidate the specific role of the transcription factors CREB, SRF, and MEF2 in the depression and potentiation components of ODP in vivo, therefore better informing future attempts to find therapeutic targets for diseases where activity-dependent plasticity is disrupted.

\section{Introduction}

Activity-dependent neuronal plasticity involves processes of both gain and loss of function, that together result in functional and structural changes in the brain. Gain of function processes include long-term potentiation (LTP), sprouting of dendrites and terminals, enlargement of boutons, and formation of new syn-

\footnotetext{
Received March 21, 2017; revised April 30, 2017; accepted May 29, 2017.

Author contributions: N.S.P., S.M.M., and A.E.M. designed research; N.S.P., W.d.S.R.J., and D.A.A. performed research; N.S.P. and A.E.M. analyzed data; N.S.P. wrote the paper.

This work was supported by NIH Grants R01AA22455 and R01AA13023.

The authors declare no competing financial interests.

Correspondence should be addressed to either Alexandre E. Medina or Nisha S. Pulimood, University of Maryland

Baltimore, 655 West Baltimore Street, Bressler Research Building, Room 13-017, Baltimore, MD 21201. E-mail: amedinadejesus@peds.umaryland.edu or nishapulimood@umaryland.edu.

DOI:10.1523/JNEUROSCI.0766-17.2017

Copyright $\odot 2017$ the authors $\quad 0270-6474 / 17 / 376628-10 \$ 15.00 / 0$
}

apses (Yuste and Bonhoeffer, 2001). Loss of function processes include long-term depression (LTD), pruning of dendrites and terminals, and elimination of boutons and synapses (Malenka and Bear, 2004; Cooke and Bear, 2013). Ocular dominance plasticity (ODP) is a paradigm of neuronal plasticity in the primary visual cortex, comprising cortical changes that take place after depriving one eye of patterned visual stimulation (Hubel and Wiesel, 1970). In this paradigm, a monocular deprivation (MD) by eyelid suture is performed, during which cortical neurons responding to the deprived and the experienced eye respectively decrease and increase their responses. ODP therefore encompasses a depression component (Dc-ODP) and a potentiation component (Pc-ODP). In mice, Dc-ODP and Pc-ODP are expressed in a temporally distinct manner, such that Dc-ODP is seen after $3 \mathrm{~d}$ of MD, whereas Pc-ODP only appears after at least 5-7 d of MD (Frenkel and Bear, 2004). 
ODP requires functional NMDA receptors and AMPA receptors (Bear et al., 1990; Roberts et al., 1998; Heynen et al., 2003; Smith et al., 2009), is highly influenced by inhibition (Hensch, 2005; Heimel et al., 2011), and is modulated by serotonergic and noradrenergic systems (Kirkwood, 2000). The calcium influx caused by activation of the aforementioned surface receptors initiate various kinase cascades that terminate in the nucleus. There, activation of transcription factors leads to the expression of plasticity-related genes, which in turn produce functional and structural changes that lead to changes in synaptic strength and consequently, ODP. Changes in the balance of excitation and inhibition during MD have been extensively studied, but much less is known about which nuclear transcription factors play a role in ODP. We are particularly interested in three transcription factors that have been heavily implicated in the expression of plasticity-related genes, namely c-AMP response element binding factor (CREB), serum response factor (SRF), and myocyte enhancer factor 2 (MEF2).

CREB, SRF, and MEF2 have been described in numerous studies for their involvement in LTP, LTD, and learning and memory (Ramanan et al., 2005; Etkin et al., 2006; Sakamoto et al., 2011; Nonaka et al., 2014; Rashid et al., 2014). With respect to ODP, work by Mower et al. (2002) showed that blocking CREB in the visual cortex prevented the effects of MD in the ferret. SRF is known to regulate the expression of the immediate early gene Arc (Pintchovski et al., 2009), the expression of which is required for ODP (McCurry et al., 2010). Additionally, LTD is disrupted in the forebrain of SRF conditional knock-out mice (Etkin et al., 2006). Activation of MEF2-dependent transcription decreases synapse number in an activity-dependent manner in hippocampal neurons in vitro (Flavell et al., 2006). Also, MEF2 overexpression blocks spatial learning, and disrupts fear memory formation by increasing AMPA receptor endocytosis (Cole et al., 2012).

Although CREB, SRF, and MEF2 may play independent roles in ODP, a recent study provided evidence that these transcription factors may act in a concerted manner. Kawashima and colleagues discovered a novel enhancer region "SARE" (synaptic activity response element), upstream of the gene Arc. SARE consists of binding sites for all three transcription factors: CREB, SRF, and MEF2, and mutating any one of these sites decreases expression of $\operatorname{Arc}$ (Kawashima et al., 2009). Interestingly, SARE has also has been identified upstream of many other plasticityrelated genes (Rodríguez-Tornos et al., 2013), suggesting that CREB, SRF, and MEF2 could regulate plasticity through a variety of different means. Here we hypothesize that SRF, MEF2, and CREB are all crucial for visual cortex plasticity and we predict that blocking each one will impair ODP. In addition, we test whether blockade of these transcription factors affects Dc-ODP, Pc-ODP, or both.

\section{Materials and Methods}

Animals. C57BL/6 mice were either directly sourced from the University of Maryland School of Medicine Veterinary Resources or were offspring of breeding pairs from Jackson Laboratories. Animals between the ages of postnatal day (P)25 and P35 were used for the electrophysiological experiments to restrict recordings to the critical period of visual cortex development. Similar numbers of males and females were used in every group to confirm that there were no sex-related effects present. All animals were used in accordance with the protocols of the University of Maryland School of Medicine Institutional Animal Care and Use Committee.

HSV constructs. The CREB-dn viral construct has a serine to alanine substitution at the critical residue 133 (S133A), which prevents phosphorylation of CREB, and subsequently blocks activation of its transcription factor function. The SRF-dn and MEF2-dn constructs are composed of their respective DNA binding domains, but lack their transactivation domains. These forms of SRF and MEF2 can therefore bind DNA, but cannot trigger the expression of genes downstream (Fig. 1A). CREB-dn, SRF-dn, and GFP control viruses were generated by Rachel Neve at the MIT Viral Core. MEF2-dn construct was generously provided to us by Dr. Sheena Josselyn at the University of Toronto.

Western blotting. To validate the viruses, mice were injected with the desired HSV construct, and the expression level of proteins dependent on each transcription factor was assessed by Western blot. After allowing 2-4 d for viral infection, spread, and downstream block of gene expression, the mice were killed with isoflurane followed by decapitation. Their brains were extracted and the visual cortex dissected out on ice. GFPpositive tissue was identified under the fluorescent microscope, microdissected and homogenized in RIPA lysis buffer (Millipore, 20-188) with protease/phosphatase inhibitors (Cell Signaling Technology, 5872). A Bradford assay was performed to determine protein concentration and equally loaded samples were run on 4-15\% TGX Protean gels (Bio-Rad), in the mini-protean Bio-Rad Tetracell electrophoresis chamber. Gels were transferred on PVDF membrane using the Bio-Rad Trans-blot turbo transfer system. Membranes were incubated overnight $4^{\circ} \mathrm{C}$ with primary antibodies as described in Table 1. Cyclophilin B was used as the loading control in all cases. Horseradish peroxidase-conjugated secondary antibodies used are also listed in Table 1. ECL reagents (Bio-Rad CLARITY) were used to chemiluminescently visualize the protein on an imaging system (ProteinSimple FluorChem HD2). ImageJ (RRID: SCR_003070) was used for densitometry and all OD values were normalized by loading control. Western blots for the developmental time points were performed on naive mice using similar conditions as described above by the University of Maryland School of Medicine Center for Innovative Biomedical Resources.

Immunofluorescence. In a different cohort of animals, after $3 \mathrm{~d}$ of virus infection in vivo, mice were perfused with cold $4 \%$ paraformaldehyde. The brain was extracted, cryoprotected, and $35 \mu \mathrm{m}$ coronal sections were made on the cryostat. A free-floating immunohistochemistry protocol was then performed. Briefly, the sections were permeabilized and blocked in $10 \%$ normal goat serum in $1 \times$ PBS with $0.5 \%$ Triton X-100 and $1 \%$ heat-shock-treated bovine serum albumin. They were then incubated at $4^{\circ} \mathrm{C}$ overnight with primary antibodies: rabbit anti-NeuN (1:500, CST-24307) and rabbit anti-GABA (1:250, Sigma-Aldrich, A2052). The next day, the sections were washed in $1 \times$ PBS-Triton, incubated for $1 \mathrm{~h}$ at room temperature with fluorescent secondary antibody (1:250, AlexaFluor 594), washed again in $1 \times$ PBS and then mounted to gelatin subbed slides with Prolong Gold anti-fade reagent with DAPI (Invitrogen).

Confocal imaging and colocalization analysis. Confocal imaging was performed at the University of Maryland School of Medicine Confocal Microscopy Core Facility, on a point-scanning confocal (Zeiss LSM 510 Meta) microscope, with a $40 \times / 1.3$ NA oil-immersion objective. Specifications for data collection on each fluorescent track were as follows: for GFP, $488 \mathrm{~nm}$ laser excitation was band-passed from 500 to $550 \mathrm{~nm}$; for AlexaFluor 594, laser excitation at $543 \mathrm{~nm}$ was set to a long-pass filter at $560 \mathrm{~nm}$; and for DAPI, $730 \mathrm{~nm}$ pulsed two-photon laser excitation was band-passed at $380-550 \mathrm{~nm}$. Colocalization analysis was performed on maximum projection images using the Grid and Cell Counter tools in ImageJ software, and visually assessing the simple yes/no question of how many GFP-positive cell bodies coexpressed NeuN or GABA (AlexaFluor 594).

Visually evoked potentials experimental timeline. At an age between P24-P26, a different cohort of mice were injected with the desired HSV construct and chronic microelectrodes were implanted. After $2 \mathrm{~d}$ of recovery from surgery, they were habituated to the recording setup, where they rest inside a protective, nonrestraining tube. Baseline visually evoked potentials (VEPs) were recorded during stimulation of each eye independently. Following this, a monocular deprivation was performed, no later than at P28 (peak of the critical period). The animals remained visually deprived for a $7 \mathrm{~d}$ period, after which the eye was reopened and VEPs were again recorded. This generates a pre-MD and post-MD VEP recording for within-subject, paired analysis. Detailed methods for virus 
A
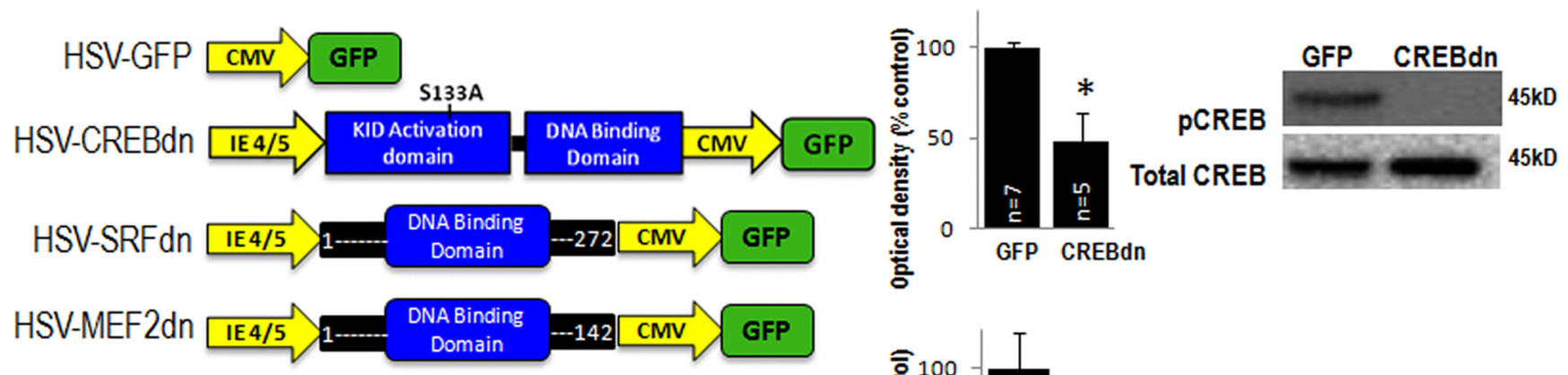

B
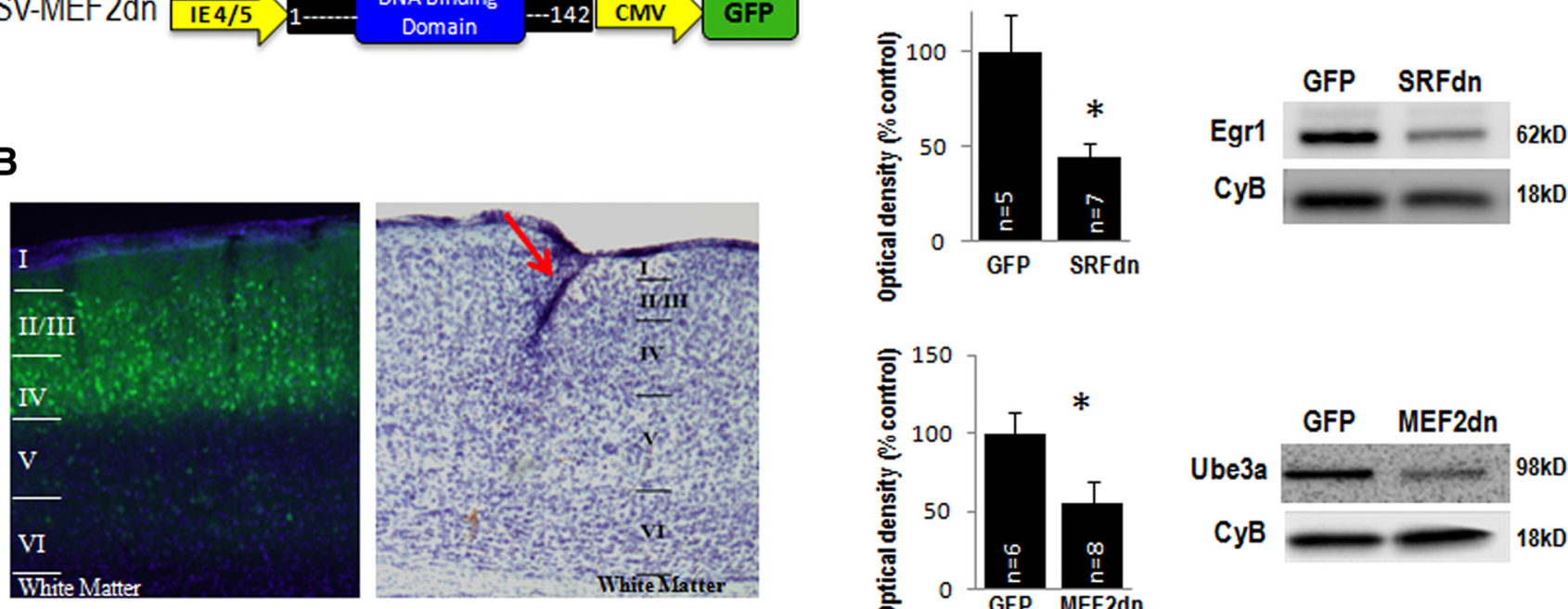

\section{C}
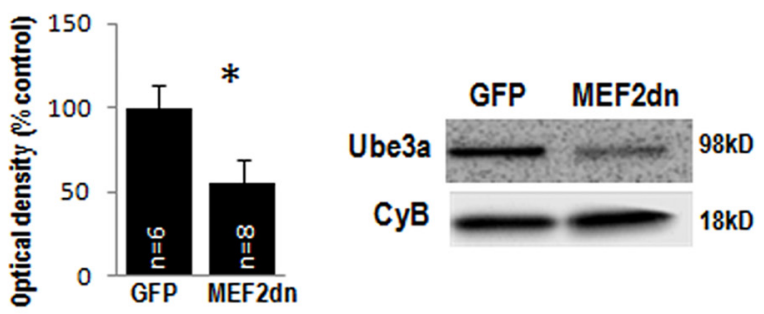

Figure 1. Virus expression and functional validation in vivo. A, Schematic diagrams of HSV viral vectors showing the CREB, SRF, and MEF2 dominant-negative constructs (CREB-dn, SRF-dn, MEF2-dn) as well as the GFP-control construct. IE 4/5 is an HSV promoter driving expression of the indicated regions of CREB, SRF, and MEF2. CMV (cytomegalovirus) promoter is driving GFP expression. $\boldsymbol{B}$, Left, GFP expression shows in virus-infected cells in all superficial layers (I-IV) of mouse V1. DAPI is stained in blue. Right, A section stained with cresyl violet showing the different cortical layers as well as the track of the electrode recording from layer IV indicated by the red arrow. C, A lower-magnification image of GFP (virus infection) and DAPI shows the lateral extent of the spread of infection in V1. The red arrow indicates the location of needle entry and electrode implantation. $\boldsymbol{D}$, Expression of $p$ CREB/totalCREB is decreased in the visual cortex of mice injected with CREB-dn compared with GFP control $\left(t_{(6)}=3.20, p=0.02 ; \mathrm{GFP} n=7\right.$, CREB-dn $\left.n=5\right)$. Egr1, an SRF-dependent gene, is reduced in visual cortices injected with SRF-dn $\left(t_{(10)}=3.02, p=0.01\right.$; GFP $n=5$, SRF-dn $n=7)$. Expression of the MEF2-dependent gene Ube3a is reduced in mice injected with MEF2-dn compared with GFP control $\left(t_{(12)}=2.18, p=0.05 ;\right.$ GFP $n=6$, MEF2-dn $n=$ 8). CyclophilinB (CyB) was used as loading control.

Table 1. Primary and secondary antibodies used for Western blotting

\begin{tabular}{|c|c|c|c|c|}
\hline Antibody name & Dilution & Species source & Company & RRID \\
\hline Phospho-CREB (Ser133) & $1: 1000$ & Rabbit & Millipore Catalog \#06-519 & AB_310153 \\
\hline CREB & $1: 5000$ & Rabbit & Millipore Catalog \#04-218 & $A B \_1586958$ \\
\hline Egr1 & $1: 1000$ & Rabbit & Santa Cruz Biotechnology Catalog \#sc-110 & AB_2097174 \\
\hline Ube3a & $1: 1000$ & Rabbit & Cell Signaling Technology Catalog \#7526S & $A B \_10971637$ \\
\hline SRF & 1:1000 & Mouse & Santa Cruz Biotechnology Catalog \#sc-25290 & AB_2239787 \\
\hline MEF2 & $1: 1000$ & Goat & Santa Cruz Biotechnology Catalog \#sc-13917 & $A B \_2142728$ \\
\hline Cyclophilin B & $1: 10,000$ & Rabbit & Thermo Fisher Scientific Catalog \#PA1-027A & $A B \_2169138$ \\
\hline Anti-rabbit lgG & $1: 3000$ & Goat & Cell Signaling Technology Catalog \#7074 & AB_2099233 \\
\hline Anti-mouse lgG & $1: 3000$ & Goat & Cell Signaling Technology Catalog \#7076 & $A B \_330924$ \\
\hline Anti-goat lgG & $1: 3000$ & Rabbit & KPL Catalog \#14-13-06 & \\
\hline
\end{tabular}

This table contains a list of all primary (rows 1-7) and secondary (rows 8-10) antibodies used for Western blotting, along with specifications like concentration used, species source, company name, product number, and RRID. 
A
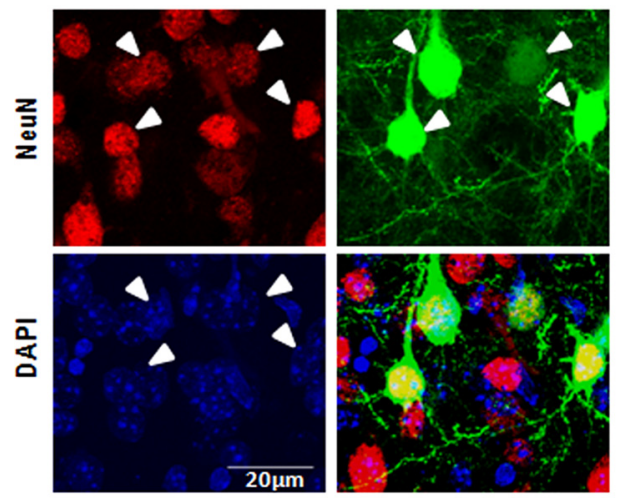

竞

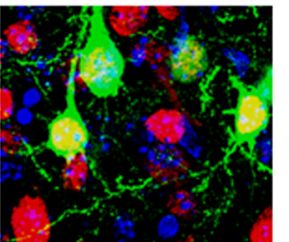

B
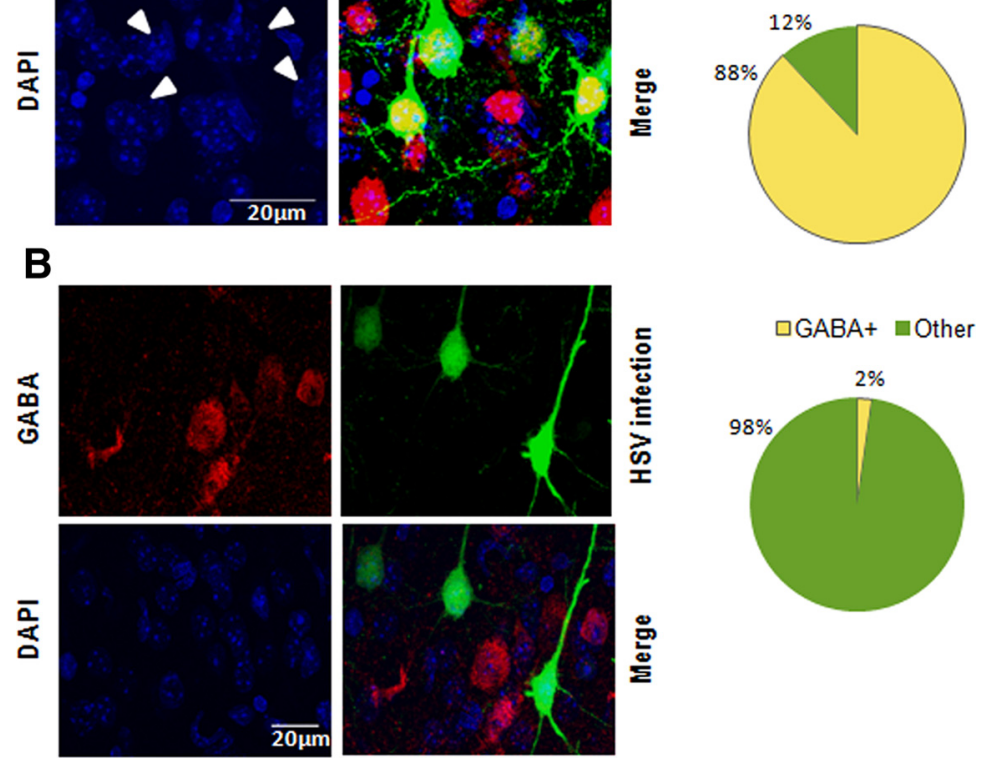

Figure 2. Cell-type specificity of viral constructs. $A, B$, Confocal images show clearly that HSV-infected cells colocalize with the vast majority of NeuN-positive neurons, however they do not colocalize with GABA containing inhibitory neurons. White arrowheads indicate virus infected neurons (colocalized for GFP and NeuN). C, Pie charts show quantification of this cell type specificity $88 \%$ of the virus-infected cells ( $n=4$ animals, $213 \pm 37$ cells/animal) are neurons and only $2 \%$ virus-infected cells $(n=4$ animals, $199 \pm 13$ cells/animal) are inhibitory.

injection, electrode implantation, $\mathrm{MD}$, and VEP recordings are described below.

Electrode implantation and intracortical injection. Surgery was conducted on mice under isoflurane anesthesia. The fur on the mouse's head was shaved and the surgical site cleaned with betadine and alcohol. Marcaine (Hospira) was topically applied, and a skin incision was made exposing a region from the occipital portion of the skull up to bregma. Burr holes were drilled at $0.5 \mathrm{~mm}$ rostral to lambda and $3 \mathrm{~mm}$ lateral to the midline, which corresponds to the binocular zone of the visual cortex (V1B) in mice. A microsyringe pump controller (World Precision Instruments, Micro4) was used to bilaterally deliver $1 \mu \mathrm{l}$ of the desired HSV construct into layer 4 of the cortex at an infusion rate of $1 \mathrm{nl} / \mathrm{s}$ with a diffusion time of 2-3 min. As seen in previous studies, injections targeted to cortical layer 4 result in robust infection of cells in layer 4 and $2 / 3$, and few cells in deeper layers 5 and 6 (Yoon et al., 2009). Tungsten electrodes (FHC) with tip impendences between 0.3 and $0.55 \mathrm{M} \Omega$ were stereotaxically implanted bilaterally in the same location as the injection, at a depth of $450-480 \mu \mathrm{m}$ to target layer 4 cells as previously described (Porciatti et al., 1999; Heynen and Bear, 2001; Lantz et al., 2015). Reference electrodes were implanted at $\sim 0.5 \mathrm{~mm}$ caudal to bregma and $2 \mathrm{~mm}$ lateral to the midline, avoiding any visible blood vessels. The four electrodes as well as a vertical post (for immobilization during VEP recordings) were secured to the skull with cyanoacrylate, creating a fixed headstage from which chronic VEP recordings were made.

Monocular deprivation. Surgery was conducted under isoflurane anesthesia, on mice between P27 and P28. The fur around the eye was clipped, and the eyelashes trimmed. Ophthalmic proparacaine (AKORN) was applied topically, and the edges of the upper and lower eyelids trimmed. The lids were stitched together using 7-0 prolene suture (Ethicon) and Gluture tissue glue (Abbott Laboratories) sealed the lids together. A thin film of cyanoacrylate was used to cover the area to protect the surgical site during the $7 \mathrm{~d}$ period of MD.

VEP recordings. This VEP recording procedure was performed the same way for both pre-MD and post-MD recording sessions. The animals' heads were immobilized so that movement artifact was kept to a minimum during electrophysiological recordings. Mice were then presented with a visual stimulus to each eye independently, during which visually evoked local field potentials were recorded. Recordings were conducted using XCell-3 amplifiers (FHC), a 1401 digitizer (CED), and Spike 2 software (Cambridge Electronics Design). XCell-3 amplifiers were set at a low-frequency cutoff of $0.1-10 \mathrm{~Hz}$ and a high-frequency cutoff of $100 \mathrm{~Hz}$. The visual stimulus consisted of a full-field phase-reversing ordinal sine grating at $0.5 \mathrm{~Hz}$ with $100 \%$ contrast, was controlled by a custom program written in MATLAB (MathWorks), and was presented at a distance of 21 $\mathrm{cm}$ from the animal. The angle of the stimulus was changed $\left(45^{\circ}-35^{\circ}\right)$ for sessions before and after monocular deprivation, to avoid any confounds with respect to stimulus-selective response potentiation (Cooke and Bear, 2010). Recordings were made of at least 100 stimulus presentations, and peak to trough amplitudes were measured. As in previous studies, compensation for variations in noise and impedance was conducted (You et al., 2012; Makowiecki et al., 2015). The average distance of each data point from the mean of all data points in each analyzed recording was determined for both pre-MD and post-MD recordings. A ratio of this mean difference was then multiplied by the peak to trough measure of the post-MD field potential to reach post-MD VEP amplitude. Contralateral bias indices (CBIs) were calculated as the ratio of the contralateral VEP amplitude over the ipsilateral VEP amplitude for each animal.

Statistics. All VEP experiments assessing ODP (CBI or VEP amplitudes) were analyzed using directional paired $t$ tests because this in vivo technique allows for within-subject controls. One-way ANOVA was used to analyze differences in VEP amplitudes and CBI between naive mice and each virus-infected group. All Western blots were analyzed by twotail independent $t$ tests. Western blots for the developmental timeline were analyzed by one-way ANOVA for the age effect, and two-tail independent $t$ tests (with Bonferroni correction) were done to specifically analyze two pairwise comparisons of interest. For clarity, some statistics details may not be included in the main text, but all values (degrees of freedom, test statistic and exact $p$ value, post hoc comparisons, sample sizes) are reported in full in the figure legends. All statistical tests were performed on IBM SPSS (v23) and statistical significance was set to $p \leq$ 0.05 , or $p<0.03$ (with Bonferroni correction) and denoted by an asterisk $\left.{ }^{*}\right)$. When referring to a statistical trend in this study, we considered $p$ values $0.05-0.08$, denoted by a hashtag (\#).

\section{Results}

Here we tested the hypothesis that SRF, MEF2, and CREB are all crucial for visual cortex plasticity and we predicted the blocking each one would impair ODP. In addition, we tested whether blockade of these transcription factors would affect Dc-ODP, Pc-ODP, or both. The HSV constructs used in our experiments also express GFP, allowing for visualization of viral expression in the brain (Fig. 1B). Injection of the vectors leads to robust expres- 
sion of GFP within $24 \mathrm{~h}$ of injection and can be seen up to $10 \mathrm{~d}$ later.

To validate that the viruses were indeed blocking transcription factor function in vivo, we conducted a series of Western blots in virus-infected tissue. We measured the level of phosphoCREB present in the visual cortex of mice injected with the CREB-dn virus versus GFP-control virus, and found that the proportion of phospho-CREB to total CREB is significantly lower in CREB-dn virus-infected samples (Fig. 1C). Egr1 and Ube3a are regulated by SRF and MEF2, respectively, and immunoblots show that there is a significant decrease in the expression of these target genes in their corresponding virus-infected tissue samples compared with GFP control virus-infected samples (Fig. $1 C ; p \leq$ 0.05 , individual $p$ values are shown in the legend).

To confirm the cellular tropism of HSV to infect excitatory neurons (Yoon et al., 2009), we used confocal imaging and colocalization analysis of the infected cells labeled with NeuN or GABA antibodies. The majority all HSV-infected cells (88\%) were NeuN-positive, and only $2 \%$ showed colocalization with neurons containing GABA (Fig. 2). This finding quantitatively confirms the neurotropic feature of the HSV vector and further suggests that the effects observed in this study are specific to CREB, SRF, and MEF2 function in excitatory neurons. We also confirmed that virus infection does not affect normal binocularity and signal strength in the visual system. None of the virusinfected mice showed significant differences in CBI at baseline compared with naive mice (Fig. $3 A ; F_{(4,116)}=1.52, p=0.20$ ). Moreover, the absolute amplitude of their VEPs at baseline were similar to naive mice $\left(F_{(4,122)}=0.845, p=0.50\right.$; Fig. $\left.3 B\right)$.

To assess whether ODP is affected by blocking CREB, SRF, or MEF2, we recorded VEPs in V1B of awake animals before and after a $7 \mathrm{~d}$ period of monocular deprivation. This technique allows us to compare amplitude changes in the evoked field potentials generated by the same mouse after plasticity occurs in its visual cortex. Since the animals are awake during recording, there are no confounding effects of anesthesia to consider while interpreting the results. Figure $4 A$ shows a schematic representation of the mouse in the VEPs recording apparatus (top) and the VEPs experimental timeline (bottom).

The binocular zone of V1 consists of thalamocortical afferents from both the contralateral and ipsilateral eye. Because most retino-thalamic fibers in the mouse decussate at the optic chiasm before arriving in the visual cortex, normal mice have an inherent contralateral bias of evoked potentials measured in the visual cortex. This is presented as a CBI, the ratio of the amplitude of the VEP during contralateral eye stimulation over the VEP during ipsilateral eye stimulation (contra/ipsi). Changes in ocular dominance can be detected as a downward shift in CBI, which indicates normal plasticity in V1B. To test our hypothesis that blockade of either CREB, SRF, or MEF2 in the visual cortex would block ODP in vivo, we compared the change in CBI after MD in CREB-dn-, SRF-dn-, and MEF2-dn-injected mice compared with mice injected with the GFP-control virus. Control mice exhibited a clear ocular dominance shift $(p=0.0004)$, whereas CREB-dn-injected mice showed a statistical trend without reaching significance ( $p=0.07$; Fig. $4 B$ ). The requirement of CREB for normal expression of ODP in vivo has previously only been observed in ferrets (Mower et al., 2002), and our study now extends this finding to rodents. A similar result was observed with MEF2-dn $(p=0.17)$, providing the first evidence toward the need for MEF2 in ODP (Fig. 4B). Unexpectedly however, SRF$\mathrm{dn}$-injected mice showed a significant decrease in CBI, similar to control $(p=0.02$; Fig. $4 B)$.
A Baseline CBI

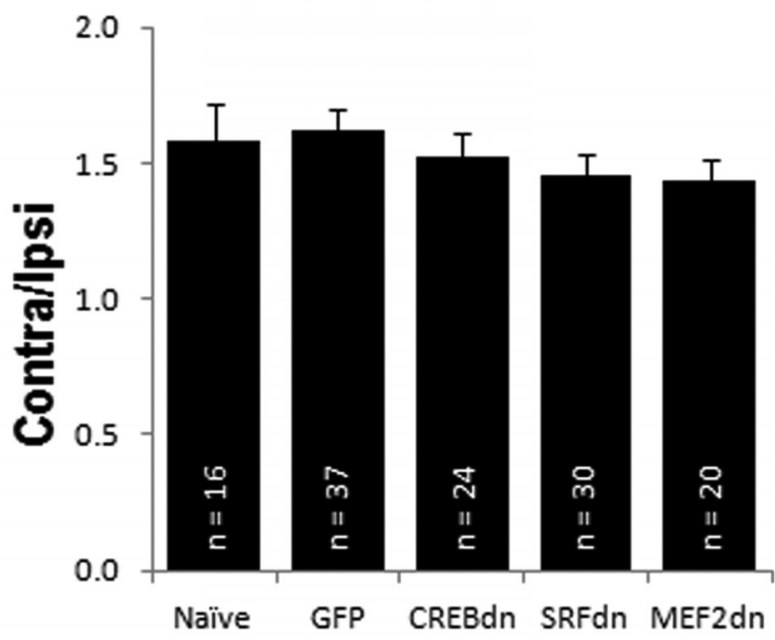

B

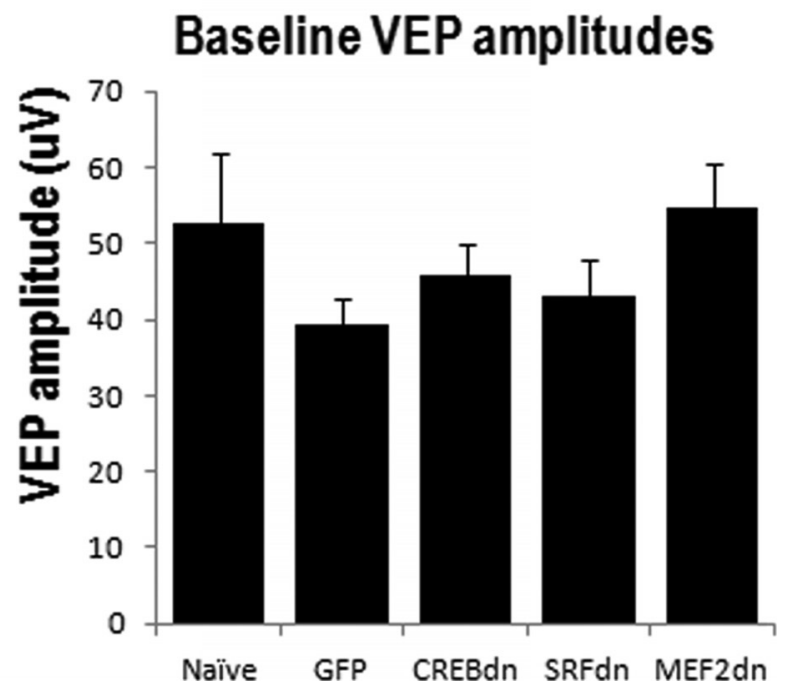

Figure 3. Virus infection does not affect normal visual responses. All mice with a stable baseline VEP recording were included here. $A$, Baseline CBls are similar in naive mice, and mice injected with any of the HSV constructs. $\boldsymbol{B}$, Absolute VEP amplitudes at baseline are not different between naive mice and virus-infected animals.

Since CBI is a ratio of contra/ipsi, this metric encompasses both the Dc-ODP as well as Pc-ODP. We examined the data further to ask which individual plasticity components (Pc-ODP or Dc-ODP), if any, required the action of CREB, SRF, and MEF2. As described previously in naive mice, VEP amplitude upon contralateral eye stimulation is expected to decrease after $7 \mathrm{~d}$ of MD, whereas amplitude of the VEP upon ipsilateral eye stimulation increases. Representative traces of VEPs before and after $7 \mathrm{~d}$ of MD, demonstrating normal Dc-ODP and Pc-ODP, are shown in Figure $5 A$.

Mice injected with GFP control virus showed the expected Dc-ODP and Pc-ODP after $7 \mathrm{~d}$ of MD (Fig. $5 B$; Dc-ODP: $p=$ 0.04 and Pc-ODP: $p=0.01$ ). In contrast, CREB-dn-injected animals showed no depression or potentiation, implying that CREB is required for the normal expression of both Dc-ODP and PcODP (Dc-ODP: $p=0.55$ and Pc-ODP: $p=0.33$; Fig. $5 C$ ). Interestingly, blocking SRF in the visual cortex blocked Dc-ODP while leaving Pc-ODP intact (Fig. 5D; Dc-ODP: $p=0.64$ and Pc-ODP: $p=0.01)$. In fact, upon comparing the magnitude of the poten- 
A
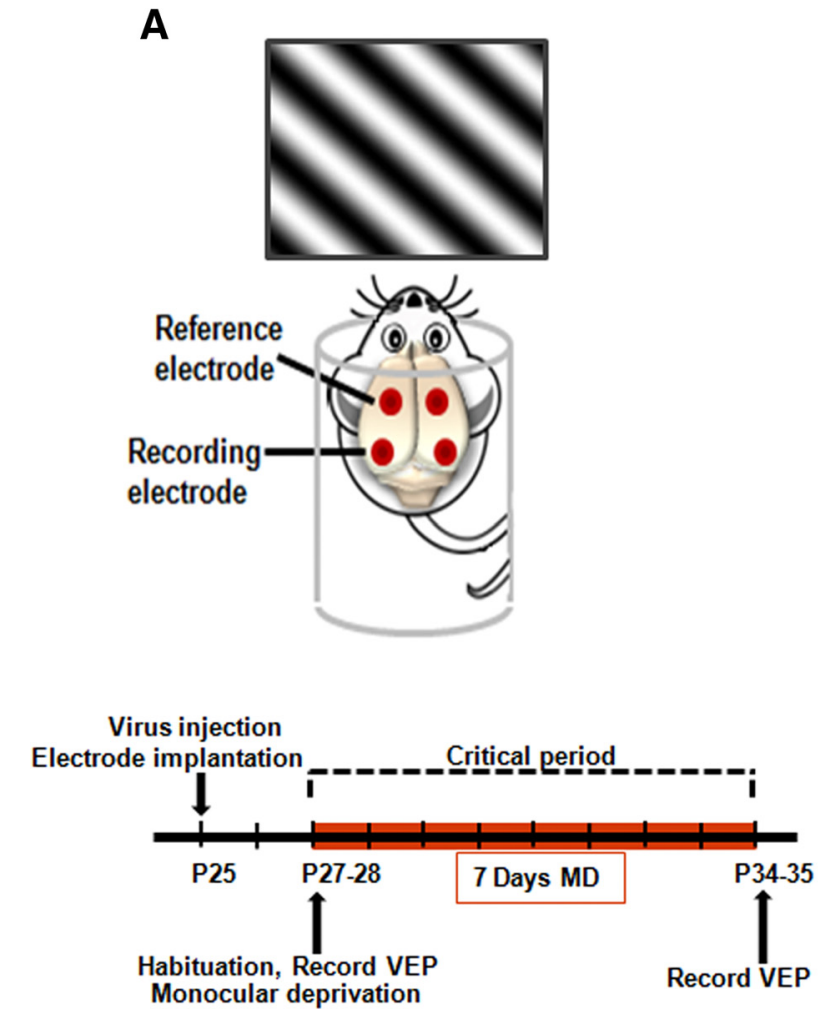

B

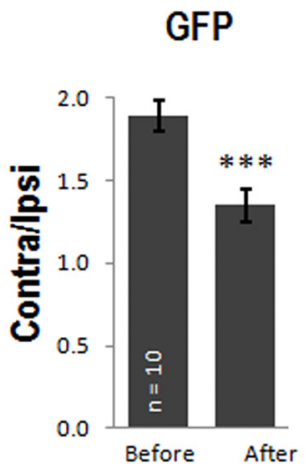

SRFdn

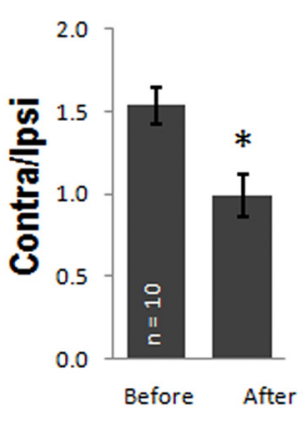

CREBdn

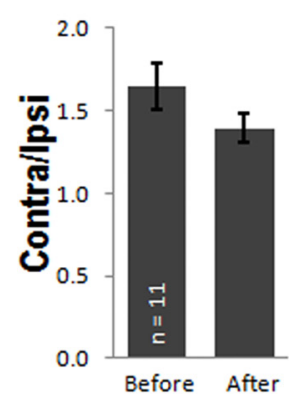

MEF2dn

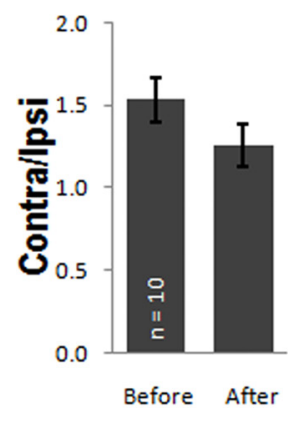

Figure 4. Blocking CREB and MEF2 block ocular dominance shift measured by CBI, but blocking SRF does not. $A$, Schematic representation of electrode implantation and VEP recordings, adapted from Singh et al. (2016). Recording electrodes are implanted bilaterally in the binocular visual cortex and reference electrodes are implanted further rostral. Cortical responses are recorded while the mouse is exposed to a visual stimulus. The experimental timeline shows the ages at which electrode implantation, VEP recordings, and MD were performed. B, CBIs (Contra/lpsi) show that CREB-dn and MEF2-dn-injected mice do not have an ocular dominance shift (CREB-dn: $t_{(10)}=2.00, p=0.07$; MEF2-dn: $t_{(9)}=1.48, p=0.17$ ), but SRF-dn-injected mice exhibit a significant shift in ocular dominance $\left(t_{(9)}=2.76, p=0.02\right)$, similar to GFP control mice $\left(t_{(9)}=7.38,{ }^{* * *} p=0.0004\right)$.

tiation in ipsilateral eye responses in SRF-dn animals compared with that of GFP-control, we found that blocking SRF caused an enhancement of Pc-ODP. The magnitude of potentiation in GFP animals was $19.3 \pm 6.3 \%$ whereas potentiation in SRF-dn mice was $72.5 \pm 20.7 \%\left(n=10, t_{(11)}=2.45, p=0.03\right)$. These results indicate that blockade of SRF blocks one component of ODP and enhances the other, and these opposing disruptions cannot be observed solely by assessing changes in CBI. MEF2dn-injected animals showed a similar pattern, with disrupted depression but normal potentiation, suggesting that MEF2 also plays a role only in Dc-ODP (Fig. $5 E$; Dc-ODP: $p=0.27$ and Pc-ODP: $p=0.05$ ).

We wanted to additionally test whether the expression levels of these essential transcription factors were altered during the critical period $(\mathrm{CP})$ of visual cortical plasticity. So we immunoblotted for CREB, SRF, and MEF2 in the visual cortex of mice at various ages during development: pre-CP (P15), the peak of the $\mathrm{CP}$ (P28), post-CP (P36), and in adult animals (>P100; Fig. 6). We found that SRF and MEF2, but not CREB expression, show a significant change across the developmental ages tested (SRF: $F_{(3,20)}=4.98, p=0.01$, MEF2: $\left.F_{(3,20)}=4.24, p=0.02\right)$. The pattern of SRF expression in particular shows a clear dip around the critical period. So we statistically compared expression levels at P28 with two other ages (P15 and adult). We found that SRF expression significantly decreases between $\mathrm{P} 15$ and $\mathrm{P} 28(p=$ 0.01 ), and shows a statistical trend to increase between P28 and adulthood ( $p=0.08)$. MEF2 shows a statistical trend to increase only between P15 and P28 $(p=0.07)$.

\section{Discussion}

Activity-dependent neuronal plasticity involves many processes of both loss and gain (LTD, LTP, shrinking of dendritic processes, spine expansion), which require an array of genes to coordinate (Maya-Vetencourt and Origlia, 2012). This makes transcription factors a useful point of therapeutic intervention because they control groups of genes that are turned on in concordance with each other to achieve a large scale cellular response. We elucidated in this study that these processes of loss and gain (Dc-ODP and Pc-ODP with respect to the visual cortex) are differentially affected by the blockade of CREB, SRF, or MEF2.

CREB, SRF, and MEF2 are known to bind the SARE enhancer region and act as concerted players in the expression of the gene Arc (Kawashima et al., 2009), which opened the possibility that they control ODP in a collaborative manner. However, they have also been independently investigated in many other paradigms of neuronal plasticity (Ramanan et al., 2005; Etkin et al., 2006; Flavell et al., 2006; Sakamoto et al., 2011; Nonaka et al., 2014; Rashid et al., 2014). Accordingly, our results showed that blocking CREB-, SRF-, or MEF2-dependent transcription in the binocular zone of $\mathrm{V} 1$ does not have the same effect on both components of ODP - only CREB is indispensable to Pc-ODP, but MEF2 and SRF are not required. In contrast, all three transcription factors are required for the expression of Dc-ODP. This suggests that the pool of genes controlled by all three transcription factors, or SARE-regulated genes, are only critical for processes of loss of function and not gain of function. 
A<smiles>C[C@H]1CC[C@H](C)C1</smiles>

Ipsieye
(Experienced) $\sqrt{50 \mathrm{~ms}}$
After MD

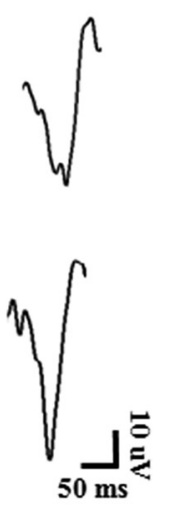

B

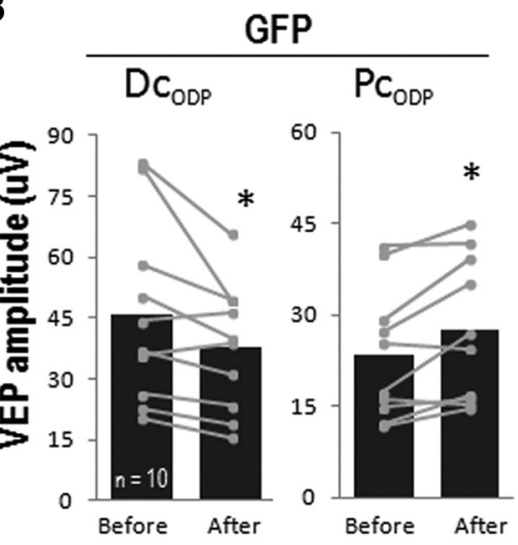

C
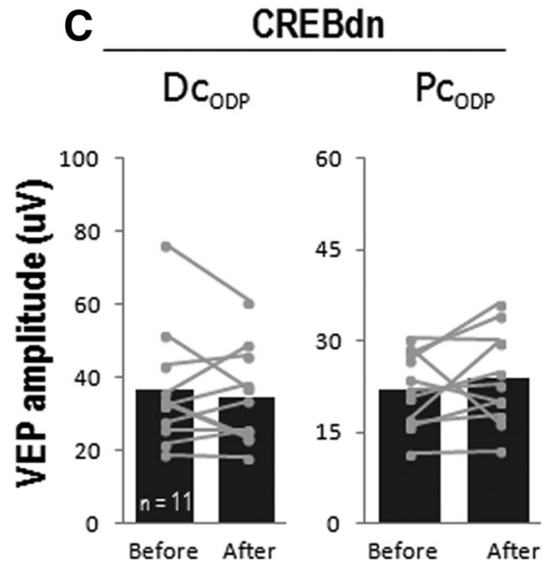

D

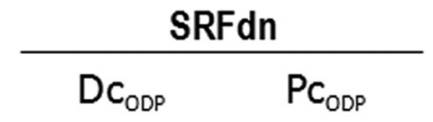

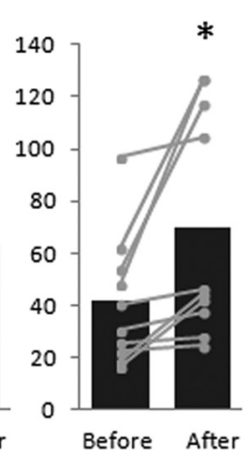

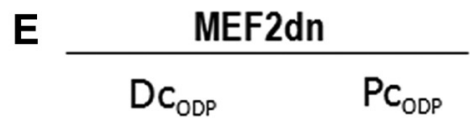

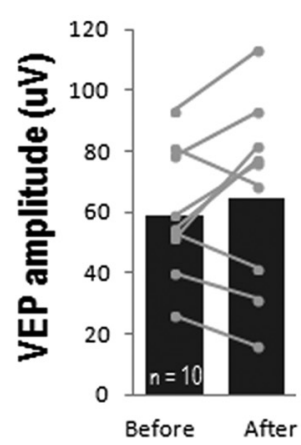

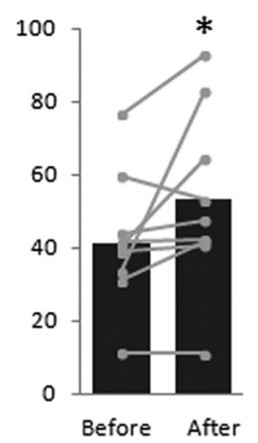

Figure 5. Blockade of CREB disrupts both DC-ODP and PC-ODP, whereas blocking SRF or MEF2 disrupts DC-ODP while leaving PC-ODP intact. $A$, Representative VEP traces after stimulation of each eye, before and after monocular deprivation. $B, A f t e r ~ 7 \mathrm{~d}$ of $\mathrm{MD}$, mice injected with GFP control virus display a decrease in cortical responses after stimulation of the deprived eye (DC-ODP) and a potentiation of responses after stimulation of the experienced eye (PC-ODP; DC-ODP: $t_{(9)}=2.44, p=0.04$ and PC-0DP: $t_{(9)}=3.06, p=0.01$ ). $C$, CREB-dn-injected animals have no DC-ODP or Pc-ODP (DC-ODP: $t_{(10)}=0.62, p=0.55$ and PC-ODP: $t_{(10)}=1.02, p=0.33$ ). D, SRF-dn-injected animals do not show DC-0DP, but have normal or even enhanced Pc-ODP (DC-ODP: $t_{(9)}=-0.48, p=0.64$ and Pc-ODP: $\left.t_{(9)}=3.01, p=0.01\right)$. $E$, MEF2-dn-injected mice also share the same pattern, with disrupted Dc-0DP, but normal PC-ODP (DC-ODP: $t_{(9)}=1.16, p=0.27$ and PC-ODP: $t_{(9)}=2.32, p=0.05$ ). Note that each line represents the VEP response of a single animal before and after MD.

A

CREB expression
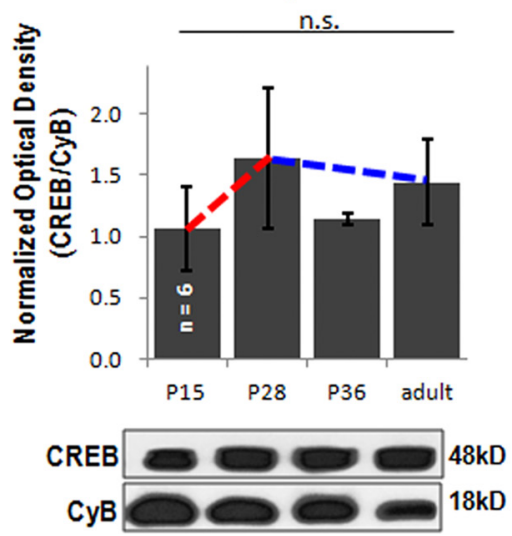

B

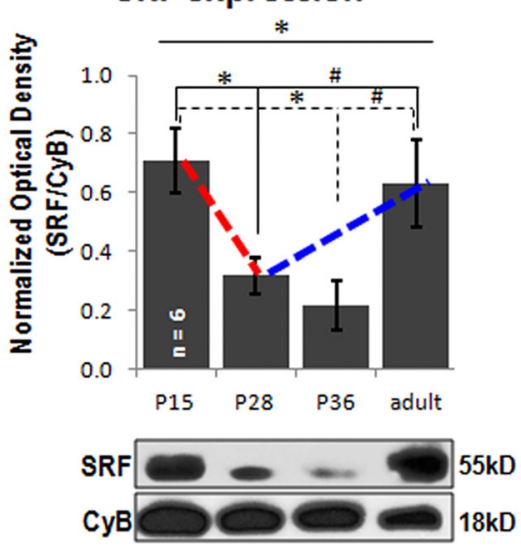

C
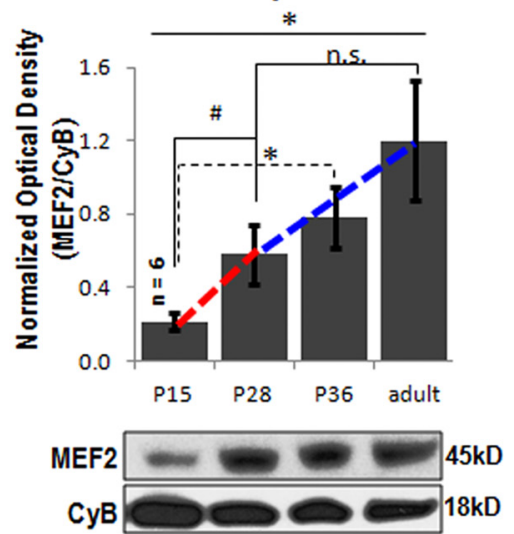

Figure 6. Expression of CREB, SRF, and MEF2 in the visual cortex along a developmental time course. $A$, Expression of CREB across development is not significant (n.s.) by one-way $\operatorname{ANOVA}\left(F_{(4,25)}=1.38, p=0.27\right)$. B , Expression of SRF changes significantly across development $\left(F_{(4,25)}=3.89, p=0.01\right)$, dropping low from P15 to P28 $\left(t_{(10)}=3.12, p=0.01\right)$ and remaining low at P36 $\left(t_{(10)}=3.56, p=0.005\right)$. There is a clear trend to increase between the critical period $(P 28)$ and adult $(>P 100)$ time points $\left(t_{(10)}=1.92, p=0.08\right)$, as well as between P36 and adult $\left(t_{(10)}=2.39, p=0.04\right)$. C, Expression of MEF2 increases significantly across development $\left(F_{(4,25)}=6.06, p=0.001\right)$ and shows a trend to increase between P15 and P28 $\left(t_{(10)}=2.17, p=0.07\right)$, reaching significance between P15 and P36 $\left(t_{(10)}=3.33, p=0.02\right)$. Note that with Bonferroni correction, statistical significance for all pairwise comparisons is set to $p<0.03$. 
We found that Dc-ODP was absent in SRF-dn-infected mice, but the magnitude of Pc-ODP was enhanced compared with that of control animals. SRF is a master regulator that controls a host of genes related to neuronal plasticity (Kuzniewska et al., 2016), many of which could contribute to its differential role in the components of ODP. For instance Npas4, an immediate early gene expressed exclusively in neurons and which regulates excitatory inhibitory balance, is controlled by SRF (Maya-Vetencourt et al., 2012; Kuzniewska et al., 2016). Specifically, Npas4 controls the number of GABA-releasing synapses on excitatory neurons (Lin et al., 2008; Spiegel et al., 2014), and the formation of inhibitory synapses on excitatory cell bodies (Bloodgood et al., 2013). Therefore perhaps a decrease in Npas4 (as is expected in the SRF-dn condition), causes a lower level of inhibition in V1B, and might result in an enhancement of activity-dependent Pc-ODP. SRF also regulates the expression of MMP9. MMP9 knock-out (KO) mice have lower spine density than wild-type, due to disrupted ability to eliminate spines in primary sensory cortices (Kelly et al., 2015). This could contribute to the lack of Dc-ODP seen in SRF-dn mice. Furthermore, the pattern of OD shift measured by optical imaging in MMP9 KOs after $7 \mathrm{~d}$ of MD (impaired depression of contralateral responses, but normal potentiation of ipsilateral responses) corroborates what we measured by VEPs in SRF-dn mice. A study by Etkin et al. (2006) showed that LTD and spatial learning is affected in SRF KO mice. In their SRF conditional $\mathrm{KO}$, they saw decreased expression of ryanodine receptor 1 and 2 (involved in calcium release from intracellular stores during LTD) as well as decreased expression of clathrin. Clathrinmediated endocytosis of AMPA receptors, a known mechanism for LTD (Wang and Linden, 2000; Bredt and Nicoll, 2003), has been shown to block the depression component of ODP (Yoon et al., 2009). Together, all these studies corroborate our finding that blocking SRF-mediated gene expression in the visual cortex disrupts Dc-ODP and enhances Pc-ODP.

At first glance, our result showing that blockade of SRF or MEF2 blocks Dc-ODP but not Pc-ODP, seems to be in disagreement with the BCM theory (Cooper et al., 1979). According to the BCM theory, the modification threshold of plasticity needs to be lowered before any potentiation can occur, implying that DcODP must occur before Pc-ODP (Cooper and Bear, 2012). However, in SRF-dn and MEF2-dn animals, we see Pc-ODP even without Dc-ODP. A possible explanation for this apparent discrepancy is that the decrease in the modification threshold after MD partly contributes to, but is not entirely responsible for, the manifestation of Dc-ODP. After MD, there is a decrease in overall activity due to loss of patterned light stimulus, which does indeed lower the modification threshold, allowing Pc-ODP to occur. However, due to the lack of SRF/MEF2-dependent gene expression, this lowered modification threshold is not expanded further into synapse silencing, elimination and other molecular mechanisms underlying the manifestation of Dc-ODP.

Our in vivo data in MEF2-dn animals is corroborated by the work of Yashiro et al. (2009). In an elegant study, they showed that an ex vivo preparation of visual cortical slices from Ube $3 a \mathrm{KO}$ mice (mouse model of Angelman's syndrome) do not show LTD after a $1 \mathrm{~Hz}$ stimulation protocol, but are able to potentiate normally after a $100 \mathrm{~Hz}$ LTP stimulation protocol. They also showed in vivo that Ube3a $\mathrm{KO}$ mice do not have Dc-ODP after $3 \mathrm{~d}$ of MD (Yashiro et al., 2009). Ube3a is a MEF2 target gene (Flavell et al., 2006), and our results in MEF2-dn mice shows blocked Dc-ODP and normal Pc-ODP, in accordance with Ube3a KO mice.

There have been studies investigating changes in CREBdependent gene expression after MD. Light exposure after a pe- riod of dark rearing during the critical period leads to activation of CREB in the visual cortex of juvenile animals, but to a much lower extent in adults (Putignano et al., 2007). Pham and colleagues showed that CREB becomes activated after MD mainly in layer 4 of V1 ipsilateral to the deprived eye, but is not affected by visual experience in the hemisphere contralateral to the deprived eye. However, these studies were conducted in the monocular zone of V1 (Pham et al., 1999, 2004), whereas the binocular zone (V1B) is more pertinent to competition-driven ODP. A majority of the work elucidating the importance of CREB in activitydependent plasticity has examined LTP and associated gain of function processes. In fact, Middei et al. (2013) showed that inhibition of CREB has opposing effects on the two components of plasticity, specifically decreasing LTP and increasing LTD. Although we also found that CREB-dn blocks Pc-ODP (which is dependent on LTP), in contrast, we observed that it blocked DcODP as well (dependent on LTD). This result can be explained via certain members of the diverse CREB transcriptome, such as the microRNA miR-132 (Vo et al., 2005), the inhibition of which was shown to prevent the effects of MD on contralateral eye responses (Mellios et al., 2011), or in other words blocking DcODP.

Our study also outlined the expression pattern of CREB, SRF, and MEF2 along a developmental time course relevant to visual cortex plasticity. We found that SRF and MEF2 display a change in expression level in the visual cortex between pre-critical period (P15) and the peak of the critical period (P28). Before the critical period (at $\mathrm{P} 10$ and P15 time points), the three transcription factors have different expression levels, alluding to potentially important roles in early development. It can be difficult to correctly predict the expression profiles of proteins such as transcription factors. Intuitively, one might expect that proteins essential for ODP should increase expression during the critical period when ODP is at its highest. However, Lyckman et al. (2008) observed that genes that are downregulated during the critical period tend to be the same genes that are upregulated during activity-dependent plasticity and vice versa. This is similar to what we found with SRF, the expression of which is downregulated at P28 but is required for activity-dependent plasticity. These results make sense in that some proteins may decrease basal expression "in preparation for" activity-dependent changes (such as after MD) at which time they are most critical.

There are a myriad of disorders in which neuronal plasticity is disrupted, such as schizophrenia, fragile X, and autism (Dölen et al., 2007; Yashiro et al., 2009; Allegra et al., 2014; Tropea et al., 2016). In addition to such disease states, the magnitude of visual cortical plasticity declines at the end of the critical period, making it more challenging to recover from trauma in adulthood (Daw et al., 1992; Sawtell et al., 2003; Suzuki et al., 2004; Nahmani and Turrigiano, 2014). Amblyopia, a condition resulting from visual deprivation or abnormal binocular interaction, cannot be fully reversed in adults due to an insufficient level of plasticity in the visual cortex after the end of the critical period (Sengpiel, 2014). To enhance plasticity in adulthood, or improve plasticity under disease conditions, it is imperative to identify the molecular players required for normal plasticity to occur. Here we have shown in vivo that CREB, SRF, and MEF2 are required for the normal expression of ocular dominance plasticity. The action of CREB, SRF, and MEF2 through SARE, and its sensitivity to neuronal activity, has been explored by several different groups (Kawashima et al., 2009; Rodríguez-Tornos et al., 2013), but these transcription factors have not been directly examined in the same study in a model of plasticity. Therefore, our work suggests that SARE could be an enhancer element for genes related more to Dc-ODP than to Pc-ODP and its associated mechanisms. 
To our knowledge, this is the first time that SRF and MEF2 have been directly implicated in ODP. CREB has been previously studied in ODP in the ferret, however, our study extends that finding to rodents as well as confirms CREB's role in each individual component of plasticity in vivo. Future studies should test whether increased function of CREB, SRF, or MEF2 is able to restore plasticity, which could be used as a potential therapeutic target in conditions of plasticity deficit.

\section{References}

Allegra M, Genovesi S, Maggia M, Cenni MC, Zunino G, SgadòP, Caleo M, Bozzi Y (2014) Altered GABAergic markers, increased binocularity and reduced plasticity in the visual cortex of engrailed-2 knock-out mice. Front Cell Neurosci 8:163. CrossRef Medline

Bear MF, Kleinschmidt A, Gu QA, Singer W (1990) Disruption of experience-dependent synaptic modifications in striate cortex by infusion of an NMDA receptor antagonist. J Neurosci 10:909-925. Medline

Bloodgood BL, Sharma N, Browne HA, Trepman AZ, Greenberg ME (2013) The activity-dependent transcription factor NPAS4 regulates domainspecific inhibition. Nature 503:121-125. CrossRef Medline

Bredt DS, Nicoll RA (2003) AMPA receptor trafficking at excitatory synapses. Neuron 40:361-379. CrossRef Medline

Cole CJ, Mercaldo V, Restivo L, Yiu AP, Sekeres MJ, Han JH, Vetere G, Pekar T, Ross PJ, Neve RL, Frankland PW, Josselyn SA (2012) MEF2 negatively regulates learning-induced structural plasticity and memory formation. Nat Neurosci 15:1255-1264. CrossRef Medline

Cooke SF, Bear MF (2010) Visual experience induces long-term potentiation in the primary visual cortex. J Neurosci 30:16304-16313. CrossRef Medline

Cooke SF, Bear MF (2013) How the mechanisms of long-term synaptic potentiation and depression serve experience-dependent plasticity in primary visual cortex. Philos Trans R Soc Lond B Biol Sci 369:20130284. CrossRef Medline

Cooper LN, Bear MF (2012) The BCM theory of synapse modification at 30: interaction of theory with experiment. Nat Rev Neurosci 13:798-810. CrossRef Medline

Cooper LN, Liberman F, Oja E (1979) A theory for the acquisition and loss of neuron specificity in visual cortex. Biol Cybern 33:9-28. CrossRef Medline

Daw NW, Fox K, Sato H, Czepita D (1992) Critical period for monocular deprivation in the cat visual cortex. J Neurophysiol 67:197-202. Medline

Dölen G, Osterweil E, Rao BS, Smith GB, Auerbach BD, Chattarji S, Bear MF (2007) Correction of fragile X syndrome in mice. Neuron 56:955-962. CrossRef Medline

Etkin A, Alarcón JM, Weisberg SP, Touzani K, Huang YY, Nordheim A, Kandel ER (2006) A role in learning for SRF: deletion in the adult forebrain disrupts LTD and the formation of an immediate memory of a novel context. Neuron 50:127-143. CrossRef Medline

Flavell SW, Cowan CW, Kim TK, Greer PL, Lin Y, Paradis S, Griffith EC, Hu LS, Chen C, Greenberg ME (2006) Activity-dependent regulation of MEF2 transcription factors suppresses excitatory synapse number. Science 311:1008-1012. CrossRef Medline

Frenkel MY, Bear MF (2004) How monocular deprivation shifts ocular dominance in visual cortex of young mice. Neuron 44:917-923. CrossRef Medline

Heimel JA, van Versendaal D, Levelt CN (2011) The role of GABAergic inhibition in ocular dominance plasticity. Neural Plast 2011:391763. CrossRef Medline

Hensch TK (2005) Critical period mechanisms in developing visual cortex. Curr Top Dev Biol 69:215-237. CrossRef Medline

Heynen AJ, Bear MF (2001) Long-term potentiation of thalamocortical transmission in the adult visual cortex in vivo. J Neurosci 21:9801-9813. Medline

Heynen AJ, Yoon BJ, Liu CH, Chung HJ, Huganir RL, Bear MF (2003) Molecular mechanism for loss of visual cortical responsiveness following brief monocular deprivation. Nat Neurosci 6:854-862. CrossRef Medline

Hubel DH, Wiesel TN (1970) The period of susceptibility to the physiological effects of unilateral eye closure in kittens. J Physiol 206:419-436. CrossRef Medline

Kawashima T, Okuno H, Nonaka M, Adachi-Morishima A, Kyo N, Okamura M, Takemoto-Kimura S, Worley PF, Bito H (2009) Synaptic activity- responsive element in the $\operatorname{arc/Arg} 3.1$ promoter essential for synapse-tonucleus signaling in activated neurons. Proc Natl Acad Sci U S A 106: 316-321. CrossRef Medline

Kelly EA, Russo AS, Jackson CD, Lamantia CE, Majewska AK (2015) Proteolytic regulation of synaptic plasticity in the mouse primary visual cortex: analysis of matrix metalloproteinase 9 deficient mice. Front Cell Neurosci 9:369. CrossRef Medline

Kirkwood A (2000) Serotonergic control of developmental plasticity. Proc Natl Acad Sci U S A 97:1951-1952. CrossRef Medline

Kuzniewska B, Nader K, Dabrowski M, Kaczmarek L, Kalita K (2016) Adult deletion of SRF increases epileptogenesis and decreases activity-induced gene expression. Mol Neurobiol 53:1478-1493. CrossRef Medline

Lantz CL, Sipe GO, Wong EL, Majewska AK, Medina AE (2015) Effects of developmental alcohol exposure on potentiation and depression of visual cortex responses. Alcohol Clin Exp Res 39:1434-1442. CrossRef Medline

Lin Y, Bloodgood BL, Hauser JL, Lapan AD, Koon AC, Kim TK, Hu LS, Malik AN, Greenberg ME (2008) Activity-dependent regulation of inhibitory synapse development by Npas4. Nature 455:1198-1204. CrossRef Medline

Lyckman AW, Horng S, Leamey CA, Tropea D, Watakabe A, Van Wart A, McCurry C, Yamamori T, Sur M (2008) Gene expression patterns in visual cortex during the critical period: synaptic stabilization and reversal by visual deprivation. Proc Natl Acad Sci U S A 105:9409-9414. CrossRef Medline

Makowiecki K, Garrett A, Clark V, Graham SL, Rodger J (2015) Reliability of VEP recordings using chronically implanted screw electrodes in mice. Transl Vis Sci Technol 4:15. CrossRef Medline

Malenka RC, Bear MF (2004) LTP and LTD: an embarrassment of riches. Neuron 44:5-21. CrossRef Medline

Maya-Vetencourt JF, Origlia N (2012) Visual cortex plasticity: a complex interplay of genetic and environmental influences. Neural Plast 2012: 631965. CrossRef Medline

Maya-Vetencourt JF, Tiraboschi E, Greco D, Restani L, Cerri C, Auvinen P, Maffei L, Castrén E (2012) Experience-dependent expression of NPAS4 regulates plasticity in adult visual cortex. J Physiol 590:4777-4787. CrossRef Medline

McCurry CL, Shepherd JD, Tropea D, Wang KH, Bear MF, Sur M (2010) Loss of arc renders the visual cortex impervious to the effects of sensory experience or deprivation. Nat Neurosci 13:450-457. CrossRef Medline

Mellios N, Sugihara H, Castro J, Banerjee A, Le C, Kumar A, Crawford B, Strathmann J, Tropea D, Levine SS, Edbauer D, Sur M (2011) miR-132, an experience-dependent microRNA, is essential for visual cortex plasticity. Nat Neurosci 14:1240-1242. CrossRef Medline

Middei S, Houeland G, Cavallucci V, Ammassari-Teule M, D'Amelio M, Marie H (2013) CREB is necessary for synaptic maintenance and learning-induced changes of the AMPA receptor GluA1 subunit. Hippocampus 23:488-499. CrossRef Medline

Mower AF, Liao DS, Nestler EJ, Neve RL, Ramoa AS (2002) cAMP/Ca ${ }^{2+}$ response element-binding protein function is essential for ocular dominance plasticity. J Neurosci 22:2237-2245. Medline

Nahmani M, Turrigiano GG (2014) Adult cortical plasticity following injury: recapitulation of critical period mechanisms? Neuroscience 283:416. CrossRef Medline

Nonaka M, Kim R, Sharry S, Matsushima A, Takemoto-Kimura S, Bito H (2014) Towards a better understanding of cognitive behaviors regulated by gene expression downstream of activity-dependent transcription factors. Neurobiol Learn Mem 115:21-29. CrossRef Medline

Pham TA, Impey S, Storm DR, Stryker MP (1999) CRE-mediated gene transcription in neocortical neuronal plasticity during the developmental critical period. Neuron 22:63-72. CrossRef Medline

Pham TA, Graham SJ, Suzuki S, Barco A, Kandel ER, Gordon B, Lickey ME (2004) A semi-persistent adult ocular dominance plasticity in visual cortex is stabilized by activated CREB. Learn Mem 11:738-747. CrossRef Medline

Pintchovski SA, Peebles CL, Kim HJ, Verdin E, Finkbeiner S (2009) The serum response factor and a putative novel transcription factor regulate expression of the immediate-early gene $\operatorname{Arc} / \operatorname{Arg} 3.1$ in neurons. J Neurosci 29:1525-1537. CrossRef Medline

Porciatti V, Pizzorusso T, Maffei L (1999) The visual physiology of the wild type mouse determined with pattern VEPs. Vision Res 39:3071-3081. CrossRef Medline

Putignano E, Lonetti G, Cancedda L, Ratto G, Costa M, Maffei L, Pizzorusso 
T (2007) Developmental downregulation of histone posttranslational modifications regulates visual cortical plasticity. Neuron 53:747-759. CrossRef Medline

Ramanan N, Shen Y, Sarsfield S, Lemberger T, Schütz G, Linden DJ, Ginty DD (2005) SRF mediates activity-induced gene expression and synaptic plasticity but not neuronal viability. Nat Neurosci 8:759-767. CrossRef Medline

Rashid AJ, Cole CJ, Josselyn SA (2014) Emerging roles for MEF2 transcription factors in memory. Genes Brain Behav 13:118-125. CrossRef Medline

Roberts EB, Meredith MA, Ramoa AS (1998) Suppression of NMDA receptor function using antisense DNA block ocular dominance plasticity while preserving visual responses. J Neurophysiol 80:1021-1032. Medline

Rodríguez-Tornos FM, San Aniceto I, Cubelos B, Nieto M (2013) Enrichment of conserved synaptic activity-responsive element in neuronal genes predicts a coordinated response of MEF2, CREB and SRF. PLoS One 8:e53848. CrossRef Medline

Sakamoto K, Karelina K, Obrietan K (2011) CREB: a multifaceted regulator of neuronal plasticity and protection. J Neurochem 116:1-9. CrossRef Medline

Sawtell NB, Frenkel MY, Philpot BD, Nakazawa K, Tonegawa S, Bear MF (2003) NMDA receptor-dependent ocular dominance plasticity in adult visual cortex. Neuron 38:977-985. CrossRef Medline

Sengpiel F (2014) Plasticity of the visual cortex and treatment of amblyopia. Curr Biol 24:R936-R940. CrossRef Medline

Singh SK, Stogsdill JA, Pulimood NS, Dingsdale H, Kim YH, Pilaz LJ, Kim IH, Manhaes AC, Rodrigues WS, Jr, Pamukcu A, Enustun E, Ertuz Z, Scheiffele P, Soderling SH, Silver DL, Ji RR, Medina AE, Eroglu C (2016) Astrocytes assemble thalamocortical synapses by bridging NRX1alpha and NL1 via hevin. Cell 164:183-196. CrossRef Medline

Smith GB, Heynen AJ, Bear MF (2009) Bidirectional synaptic mechanisms of ocular dominance plasticity in visual cortex. Philos Trans R Soc Lond B Biol Sci 364:357-367. CrossRef Medline
Spiegel I, Mardinly AR, Gabel HW, Bazinet JE, Couch CH, Tzeng CP, Harmin DA, Greenberg ME (2014) Npas4 regulates excitatory-inhibitory balance within neural circuits through cell-type-specific gene programs. Cell 157:1216-1229. CrossRef Medline

Suzuki S, al-Noori S, Butt SA, Pham TA (2004) Regulation of the CREB signaling cascade in the visual cortex by visual experience and neuronal activity. J Comp Neurol 479:70-83. CrossRef Medline

Tropea D, Molinos I, Petit E, Bellini S, Nagakura I, O’Tuathaigh C, Schorova L, Mitchell KJ, Waddington J, Sur M, Gill M, Corvin AP (2016) Disrupted in schizophrenia 1 (DISC1) L100P mutants have impaired activity-dependent plasticity in vivo and in vitro. Transl Psychiatry 6:e712. CrossRef Medline

Vo N, Klein ME, Varlamova O, Keller DM, Yamamoto T, Goodman RH, Impey S (2005) A cAMP-response element binding protein-induced microRNA regulates neuronal morphogenesis. Proc Natl Acad Sci U S A 102:16426-16431. CrossRef Medline

Wang YT, Linden DJ (2000) Expression of cerebellar long-term depression requires postsynaptic clathrin-mediated endocytosis. Neuron 25:635647. CrossRef Medline

Yashiro K, Riday TT, Condon KH, Roberts AC, Bernardo DR, Prakash R, Weinberg RJ, Ehlers MD, Philpot BD (2009) Ube3a is required for experience-dependent maturation of the neocortex. Nat Neurosci 12: 777-783. CrossRef Medline

Yoon BJ, Smith GB, Heynen AJ, Neve RL, Bear MF (2009) Essential role for a long-term depression mechanism in ocular dominance plasticity. Proc Natl Acad Sci U S A 106:9860-9865. CrossRef Medline

You Y, Thie J, Klistorner A, Gupta VK, Graham SL (2012) Normalization of visual evoked potentials using underlying electroencephalogram levels improves amplitude reproducibility in rats. Invest Ophthalmol Vis Sci 53:1473-1478. CrossRef Medline

Yuste R, Bonhoeffer T (2001) Morphological changes in dendritic spines associated with long-term synaptic plasticity. Annu Rev Neurosci 24: 1071-1089. CrossRef Medline 